\title{
Growth, Agar Yield and Water Quality Variables Affecting Mass Propagation of Tissue Cultured Seaweed Gracilaria verrucosa in Pond
}

\author{
Sri Redjeki Hesti Mulyaningrum* and Hidayat Suryanto Suwoyo \\ Research Institute for Coastal Aquaculture \\ Jl. Makmur Dg. Sitakka No. 129, Maros, South Sulawesi, Indonesia 90512 \\ Email: titut_suryanto@yahoo.com
}

\begin{abstract}
Mass propagation of tissue culture produced seaweed seedling was conducted in the pond. The present study aims to evaluate the growth of tissue culture produced seaweed seedling of Gracilaria verrucosa, its agar yield and related water quality variables during propagation in pond. The seedling propagation was conducted in pond using long line method for 9 cycles (30 days per cycle). The daily growth rate was calculated by weighing $30 \%$ of the total amount of seaweed at ropes line every 15 days. Agar yield was analyzed every 30 days in hot water extraction method. Water quality monitoring was conducted every 15 days. The data of daily growth rate and agar yield were analyzed descriptively. A simple linear regression analysis was conducted in order to analyze the relationship between growth and agar yield as well relationship between water quality variables, growth and agar yield. The result showed that the average daily growth rate of nine cycles was $3.38 \pm 1.49 \%$. The highest agar yield

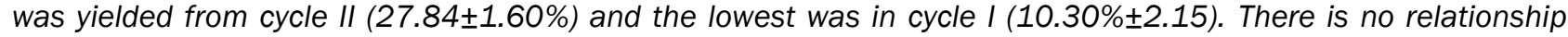
between daily growth rate and agar yield $\left(R^{2}=0.055\right)$. Daily growth rate was mostly influenced by phosphate $(P<0.05)$, nitrate $(P<0.05)$, salinity $(P<0.05)$ and light penetration $(P<0.05)$. Meanwhile, agar yield was mostly influenced by temperature $(P<0.05)$ and light penetration $(P<0.05)$. Present study promising for seaweed $G$. verrucosa mass cultivation of tissue culture product which is a feasible alternative method to supply seaweed seedlings in seaweed farming development.
\end{abstract}

Keywords: growth, agar yield, G. verrucosa, tissue culture, water quality

\section{Introduction}

Seaweed still dominates the production of the world's water plant commodity with $8 \%$ per year in recent ten years. As one of countries with great concern on tropical seaweed cultivation, Indonesia has huge contribution to increase production of world's water plants. The government policies in supporting seaweed cultivation significantly contribute to improve the global production of seaweed from $6.7 \%$ in 2005 to $36.9 \%$ in 2014 . The production of Rhodophyte Gracilaria sp. increased during 2005-2014, from 936,000 tons to $3,752,000$ tons (FAO, 2016). G. verrucosa, an exported potential seaweed species can be cultivated in ponds. There are some advantages of pond cultivation: water quality was easy to control and protected plant from several aquatic factors i.e: large waves, strong currents and predatory attacks. Production of $G$. verrucosa is continued to be increased. One strategy to provide sustainable and superior seedling is by seedling quality improvement through several methods such as clone selection (Pong-Masak et al., 2011), spore setting (Yudiati et al., 2004), and tissue culture with various techniques such as protoplast culture, somatic embryogenesis and thallus fragment culture (Suryati et al., 2007; Suryati \& Mulyaningrum, 2009; Mulyaningrum et al., 2013; Mulyaningrum et al., 2014). Tissue culture has been done on Kappaphycus alvarezii (Paula et al., 2001; Reddy et al., 2003; Muñoz et al., 2006); Eucheuma denticulatum (Hurtado-Ponce and Cheney, 2003); Heterosiphonia japonica (Husa and Sjøtun, 2006); and Gelidiella acerosa (Kumar et al., 2004). The main focus of tissue culture is for genetic improvement and clonal propagation for seaweed cultivation. Clonal propagation from simple thallus segment is the simplest vegetative propagation approach to select superior strain from wild population in order to improve quality of the seaweed. A number of studies have exploited organogenetic potential of seaweed to isolate superior clone of some high economic value species of seaweed. Eventhough this approach is considered successful, it needs a continuous monitoring and isolation of clone with superior quality for a certain characteristic as well as maintenance of selected strain. A massive production of tissue culture produced seaweed seedlings is absolutely needed to facilitate cultivation for the whole year (Reddy et al., 2008). The success of providing G. verrucosa 
seedlings through tissue culture is inseparable from the success of propagation process in the ponds. Monitoring of growth, agar yield and water quality variables which affect the seedlings growth are essential to know the response of growth and agar yield of tissue culture G. verrucosa seedling to pond condition. The present study aims to evaluate the growth of tissue cultured produced seaweed seedling of G. verrucosa, its agar yield and related water quality variables during propagation in pond.

\section{Materials and Methods}

Mass propagation of tissue culture produced seaweed seedlings was conducted in experimental ponds in Taipa village, Takalar regency, South Sulawesi. G. verrucosa seedlings obtained from tissue culture according to the previous method (Mulyaningrum et al., 2014) were propagated in the pond by applying long line method. Seedling with fresh thallus, a lot of branching and free of epiphytes was selected.

Thirty lines of rope were prepared as the equipment of cultivation. Each line has 7 meters long nylon rope with $5 \mathrm{~mm}$ diameter. Some pieces of plastic rope which functioned as strap for the seaweed clumps were tied up to the line with the distance between clumps was $15-20 \mathrm{~cm}$. Twenty grams of seaweed seedlings was tied to each clump along the lines. Then, the lines were tied to bamboo stakes with distance between stakes was $50 \mathrm{~cm}, 15$ $\mathrm{cm}$ from the bottom of the pond (Figure 1.). Nine cycles (30 d.cycle ${ }^{-1}$ ) was carried out. During the cultivation, the lines were shaken to avoid epiphytes and mud. The water in the pond was changed during high tide. Monitoring of the growth of the seaweed and water quality was carried out every 15 days. Temperature, salinity, transparency, nitrate, phosphate and nitrite were measured and the 30\% of total amount of the seaweed on the lines were weighed in every 15 days. The daily growth rate was calculated according to Dawes et al. (1993).
Agar yield was measured from triplicate random seaweed sample in 30 days. The sample was extracted in hot water, referred to the method of Angka and Suhartono (2000). Ten grams of dried seaweed was soaked in $0.25 \%$ chlorine solution for $3 \times 24$ hours. The seaweed was rinsed, cleaned and soaked in fresh water for 3 hours, then soaked in $10 \%$ sulfuric acid solution for 15 minutes; the sulfuric acid solution was then discarded and the seaweed was washed with fresh water and soaked in freshwater again for 15 minutes. After that, it was boiled in $500 \mathrm{ml}$ of aquadest, let it cool, filtered and dried under the sunlight. Finally, the dried agar was weighed. and calculated according to Kumar and Fotedar (2009).

Growth and agar yield were analyzed descriptively and presented in graphics. A simple linear regression analysis was conducted in order to determine the relationship between growth and agar yield as well relationship between water quality variables, growth and agar yield.

\section{Results and Discussion}

\section{Daily Growth Rate}

Average daily growth rate of $G$, verucossa during cultivation in the pond was $3.38 \pm 1.49 \%$. See Figure 2 . The best and lowest average daily growth rate was occurred in cycle II $(5.03 \pm 1.39 \%)$ and VII $(1.22 \pm 0.78 \%)$. G. verucossa had good growth in cycle I-early VI with daily growth rate ranged 3.19$6.01 \%$, but in the end of cycle VI-VIII it decreased to $0.66-2.89 \%$. The growth started to increase again in cycle IX with daily growth rate ranged from $2.37 \%$ to $2.48 \%$. The seaweed growth rate was greatly influenced by the weather during the cultivation which influenced the salinity of pond water. Cycles I until early VI (March until the beginning of August), the weather was relatively good with appropriate intensity of sunlight and rainfall for seaweed growth. Salinity of the pond was recorded at 4-28 ppt.

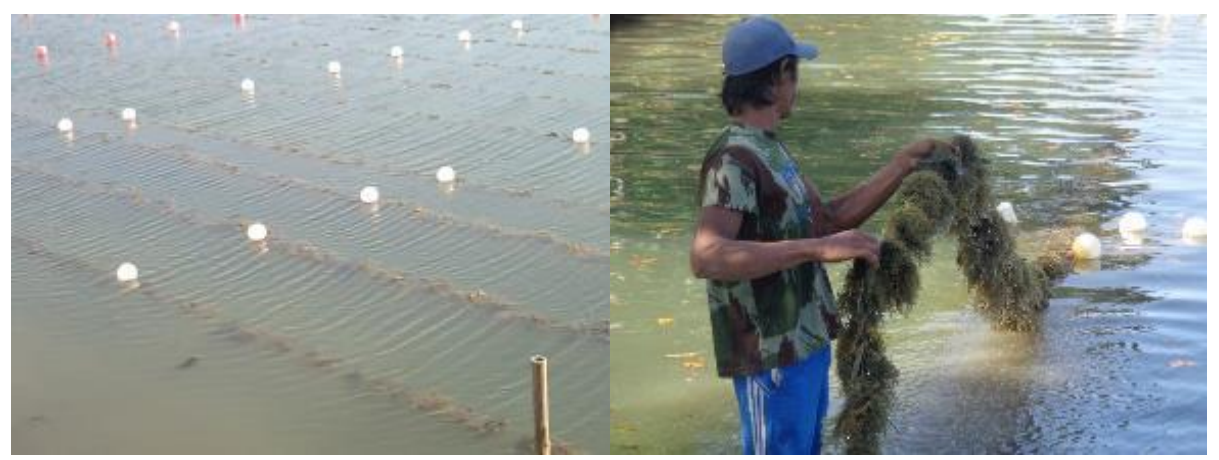

Figure 1. Mass propagation of tissue cultured seaweed seedling G. verrucosa using long line method 


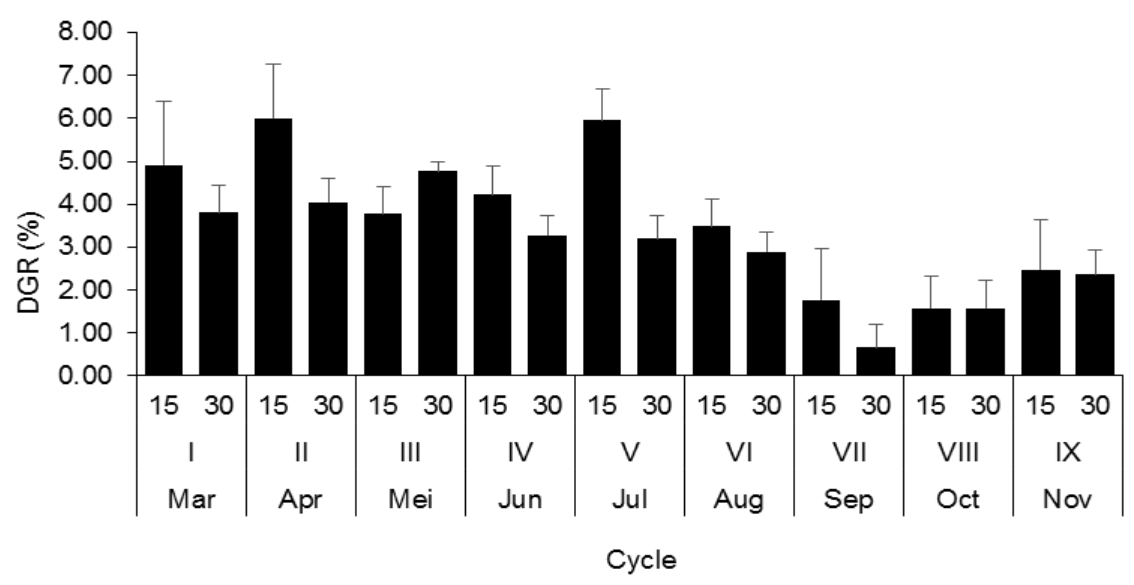

Figure 2. Growth of tissue culture produced G.verrucosa seedling in pond

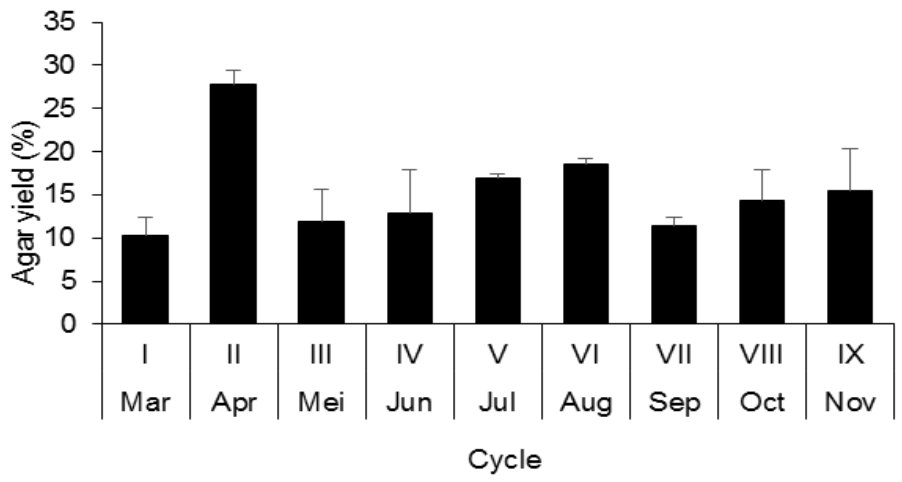

Figure 3. Agar yield tissue culture produced G.verrucosa seedling propagated in pond

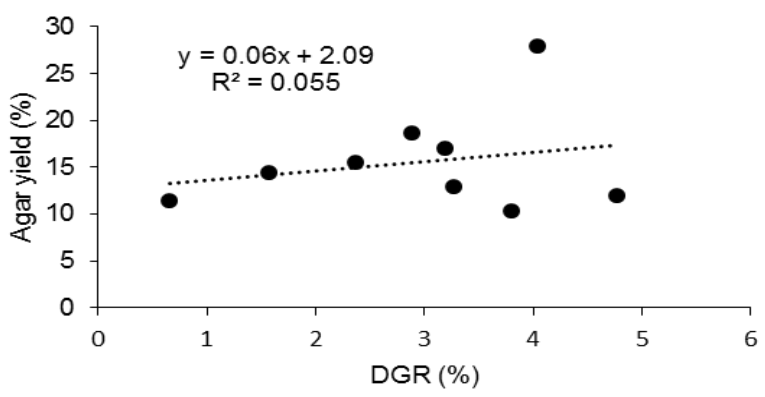

Figure 4. Relationship between growth and agar yield of seaweed tissue culture G. verrucosa

However, the dry season middle of August until October (end of cycle VI-VIII) increased the salinity to 38 ppt. Dry season also lead to decreasing supply of water so it was difficult to change the water pond. Daily growth rate has improved in cycle IX (started in November), when dry season changed into rainy season and the water salinity gradually decreased to 35-36 ppt. The daily growth rate has increased (Figure 2.). This is in accordance with Li-hong et al. (2002) which found that seaweed growth would be higher in low salinity.

The average growth of seaweed tissue culture was different from daily growth rate of Gracilaria sp. which was obtained by Hurtado-Ponce et al. (1997). The daily growth rate of Gracilaria sp. was $4.5 \%$. However, the growth is still considered well, which is corresponding to Mubarak et al. (1990) which explain that growth rate is considered advantageous if it is above $3 \%$.

\section{Agar yield}

Average agar yield of tissue cultured seaweed seedlings in nine cycles was $15.50 \pm 5.35 \%$. The highest yield was obtained in the second cycle $(27.84 \pm 1.60 \%)$ while the lowest yield was obtained in the first cycle $(10.30 \pm 2.15 \%)$ (Figure 3.). Agar is a carbohydrate of photosynthesis product, its 
formation process is influenced by light intensity. The second cycle had optimum transparency and seaweed got enough sunlight for the process of photosynthesis so that the formation of agar was higher than other cycles. Orosco et al. (1992) and Oyieke (1993) reported the yield of marine cultured G. verrucosa was $8.1-30 \%$ and $14.7 \%$, respectively.

Present study indicates no relationship between daily growth rate and agar yield of 30-dayold seaweed Figure $4(P<0.05)$. This result related to González-Gómez et al., (1992) but that the growth of seaweed related to nutrient in the water. But study by Hayashi et al. (2007), showed that carrageenan yield of Kappaphycus alvarezii decreases when the nutrient content is high and growth and carrageenan yield has negative relationship.

\section{Water quality}

Generally, the condition in the pond during the research was conducive for seaweed growth, as presented in Table 1. The temperature of the water during the research was around $25-35^{\circ} \mathrm{C}$. The lowest temperature was occurred in cycle I and the highest one was occurred in cycle II. Temperature effect on growth rate of some Gracilaria species have reported. Kim et al. (2002) reported the optimal temperature for $G$. verrucosa growth was $25^{\circ} \mathrm{C}$. G. cornea showed a significant correlation between biomass and temperature, the optimum growth occurred when seawater temperatures were below $30^{\circ} \mathrm{C}$ (Orduña-Rojas \& Robledo, 2002; Orduña-Rojas et al. 2002). Raikar et al.(2001) reported the optimum temperature for the growth of several Gracilaria species namely G. arcuata, G. textorii, G. vermiculophylla, G. incurvata, G. foliifera, G. corticata, G. edulis and G. licheniodes, found that the best temperature for the growth of Gracilaria spp. was around $20-35^{\circ} \mathrm{C}$.

The light penetration during the research was normal $(21-41 \mathrm{~cm})$. The lowes tight penetration was occurred in cycle VII and the highest one was occurred in cycle II. It corresponds with Boyd (1990) state that the range of transparency which is good for seaweed growth is around $10-40 \mathrm{~cm}$. The range of water salinity during the research was quite wide
(4-38 ppt). However, the seaweed still could grow in those range of salinity. Good seaweed growth rate was occurred in cycle I-VI with salinity ranging in 428 ppt, while low growth rate was occurred in cycle VII-VIII in dry season with 35-38 ppt of salinity range. According to Choi et al. (2006), G. verrucosa can grow well in wide range of salinity (5-35 ppt) and optimally grow in salinity range of 15-25 ppt.

Nitrate content during the research was around 0.063-13.228 mg.L-1. Nitrate content that supported seaweed growth rate was occurred in cycle I-VI and low nitrate content was occurred in cycle VII-VIII which led to low growth rate. Nitrate is considered limiting nutrient for algae growth if the content is less than phosphate in the water body. Nitrate is the best source of nitrogen for growth of several species of marine algae. Lack of nitrate is marked by bleaching of red algae tahllus. The lowest tolerable content of nitrate for algae growth is 0.1 mg.L-1, while the highest is 3 mg.L-1 (Moore, 1991).

Phosphate content in the water during the research was around 0.002-0.445 mg.L-1. The highest phosphate content was occurred in cycle II and the lowest one was occurred in cycle VII, this condition affected the growth rate of seaweed. Phosphate is also a main nutrient factor for algae. Phosphate is a dissolved compound in the water which contributes in protein formation and photosynthesis. According to phosphate content in the water, fertility rate of the pond can be categorized into three: low fertility rate has phosphate content of $0-0.02$ mg.L-1, medium fertility rate with phosphate content around 0.021 0.05 mg. $\mathrm{L}^{-1}$ and high fertility rate with phosphate content 0.051-0.2 mg.L-1. Meanwhile, nitrite content in water naturally is $0.001 \mathrm{mg} \cdot \mathrm{L}^{-1}$ and it is better not to contain nitrite more than $0.05 \mathrm{mg} . \mathrm{L}^{-1}$ because it can be toxic for the water organisms (Moore, 1991; Effendi, 2003).

The result of simple regression analysis of water quality variable and daily growth rate indicate that phosphate $\left(\mathrm{R}^{2}=0.84 ; \quad \mathrm{r}=0.917 ; \mathrm{P}=0.000\right)$, nitrate $\left(R^{2}=0.702 ; \quad r=0.838 ; \quad P=0.000\right)$ salinity $\left(R^{2}=0.765 ; r=0.875 ; \quad P=0.000\right)$ and transparency $\left(R^{2}=0.460 ; r=0.678 ; P=0.002\right)$, more significant

Table 1. Pond water quality variables during 9 cycles of seaweed tissue culture G. verrucosa cultivation $(n=18)$.

\begin{tabular}{lcccc}
\hline Variable & Minimum & Maximum & Average & Standard deviation \\
\hline Temperature $\left({ }^{\circ} \mathrm{C}\right)$ & 25 & 35 & 28.63 & 2.58 \\
Salinity $(\mathrm{ppt})$ & 4 & 38 & 30 & 10.18 \\
Transparency $(\mathrm{cm})$ & 24 & 41 & 24.94 & 5.66 \\
Nitrate $\left(\mathrm{mg.L}\right.$ - $^{-1}$ & 0.063 & 13.228 & 2.55 & 3.80 \\
Phosphate $\left(\mathrm{mg} \cdot \mathrm{L}^{-1}\right)$ & 0.002 & 0.445 & 0.16 & 0.12 \\
Nitrite $\left(\mathrm{mg.L} \mathrm{L}^{-1}\right)$ & 0.001 & 0.047 & 0.01 & 0.01 \\
\hline
\end{tabular}



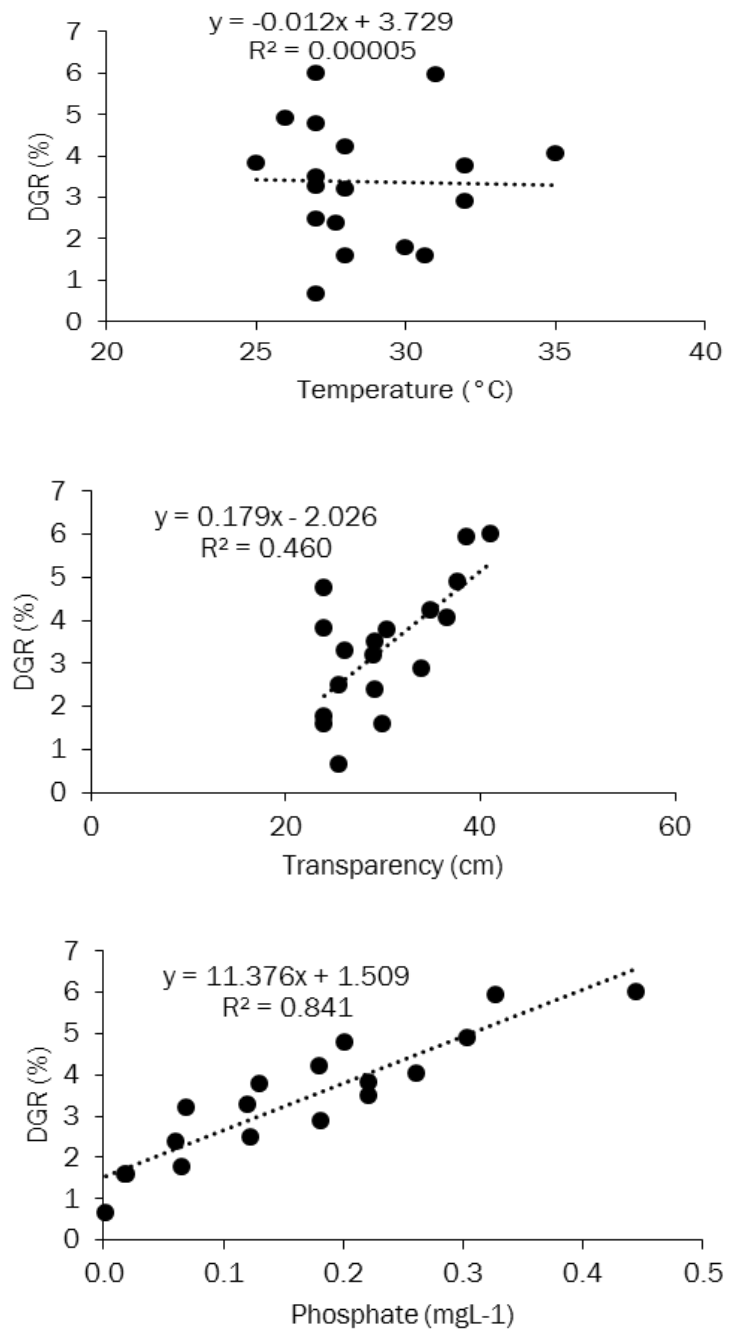
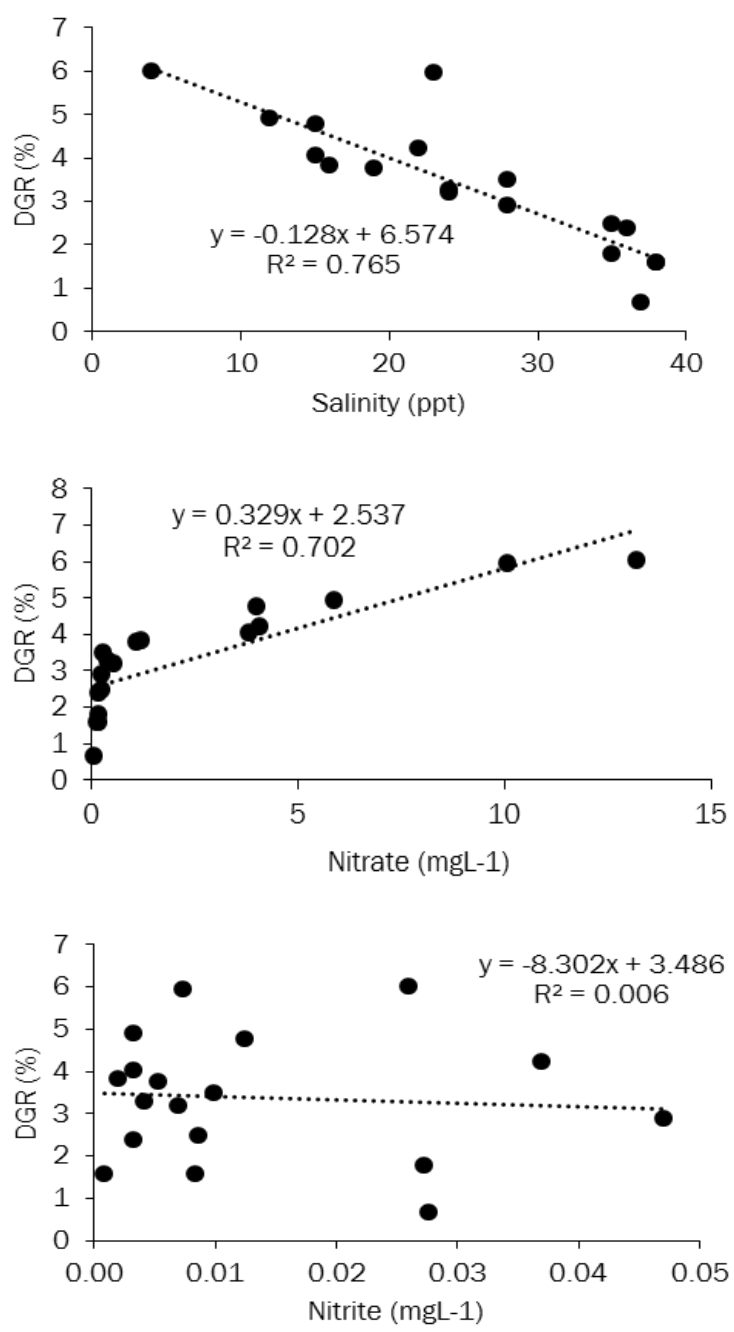

Figure 5. Relationship between daily growth rate of seaweed tissue culture produced G. verrucosa seedling and pond water quality variables

role in seaweed growth compared to other variables such as nitrite $\left(R^{2}=0.006 ; r=0.076 ; P=0.765\right)$ and temperature $\left(R^{2}=0.00005 ; r=0.021 ; P=0.933\right)$ as presented in Figure 5. Agar yield in seaweed is mostly influenced by temperature $\left(R^{2}=0.913\right.$; $P<0.05)$ and light transparency $\left(R^{2}=0.862 ; P<0.05\right)$, but not by phosphate $\left(R^{2}=0.166 ; P>0.05\right)$, nitrate $\left(R^{2}=0.150 ; P>0.05\right)$, salinity $\left(R^{2}=0.056 ; P>0.05\right)$, and nitrite $\left(R^{2}=0.0002 ; P>0.05\right)$ as presented in Figure 6.

Water quality is a factor which influences the growth and agar yield of seaweed. Ak et al. (2011) reported that organic fertilizer with high nitrate content can boost the growth of $\mathrm{G}$. verrucosa but it has negative relationship with agar yield. Araño et al. (2000) explain that light intensity and ammonium have significant influence to the growth and agar yield of seaweed both partially and simultaneously. Water quality variable, particularly temperature and transparency, play an important role in agar formation. Agar yield in seaweed increased when the transparency increased. It is understandable since temperature and transparency influence photosynthesis which produces carbohydrate in form of agar (1999; Marinho-Soriano \& Bourret, 2003).

Tissue culture with thallus fragment culture method produced from tissue cultured is a method of cultivation seedlings by vegetative clone propagation which has same characteristics with the parent. As an effort to improve the quality of seedlings produced by tissue culture, it is suggested to combine methods by selecting clone in propagation. Combination of tissue culture and molecular genetics can produce high quality seedlings (Baweja et al., 2009). According to Thirumaran and Anantharaman (2009), vegetative propagation of seaweed is an effective way to massively produce seedlings. However, it is important to consider environmental factors since they greatly influence the growth and agar yield 

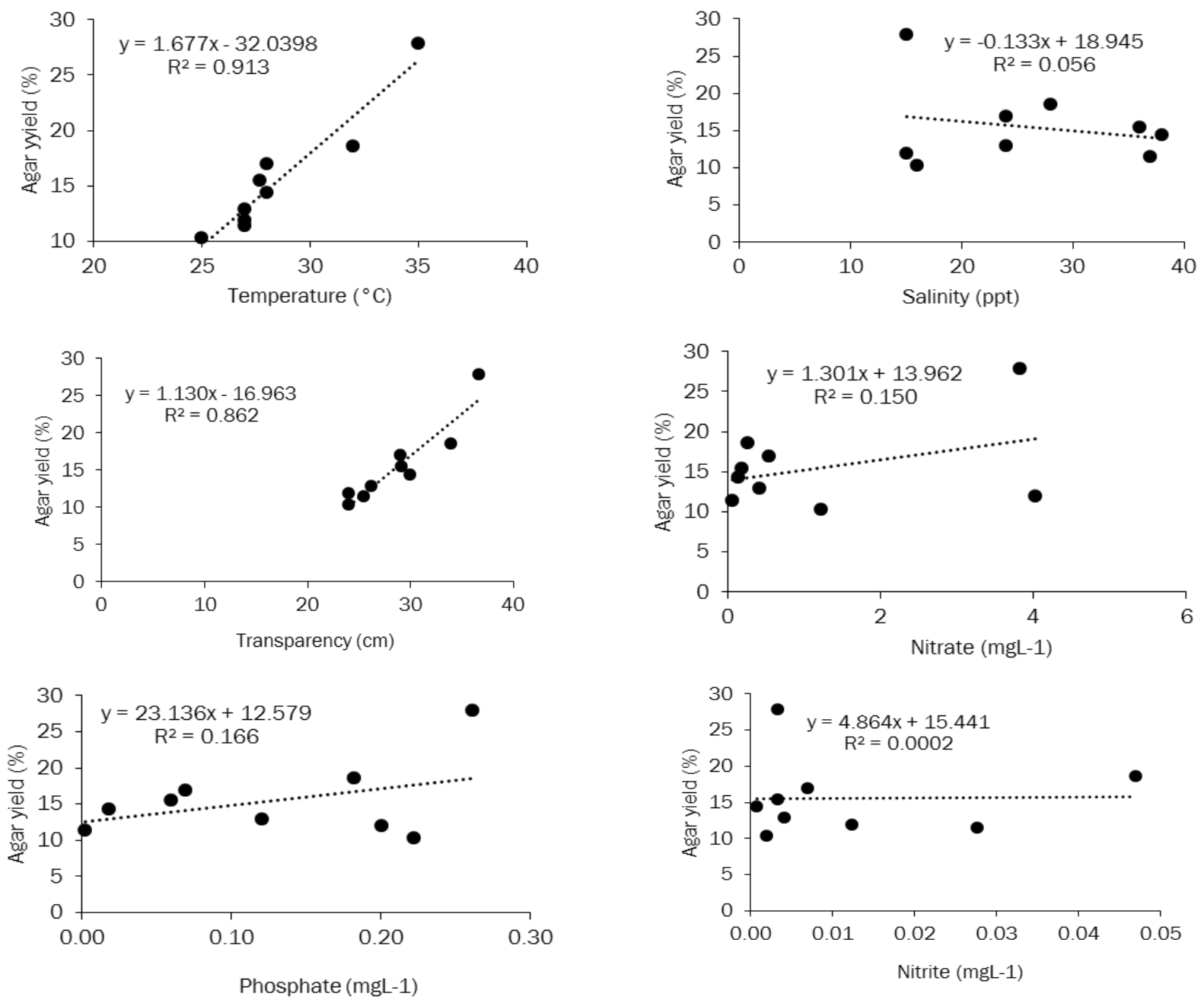

Figure 6. Relationship between agar yield of seaweed tissue culture G. verrucosa and pond water quality variables

produced (Chung et al., 2007). The results of the present study suggested that the optimal condition for seaweed cultivation in Taipa village, Takalar regency, South Sulawesi were in March until the beginning of August, when the rain and light intensity support the growth of $G$. verrucosa. Meanwhile, the middle of August until October is the time when the condition is not optimal for seaweed growth because long dry season occurs in those months.

\section{Conclusions}

Tissue cultured produced seaweed seedling daily growth rate during nine cycles was $3.38 \pm 1.49 \%$. The highest agar yield was yielded from cycle II $(27.84 \pm 1.60 \%)$ during April and the lowest was in cycle I $(10.30 \% \pm 2.15)$ during January. There is no relationship between daily growth rate and agar yield. Daily growth rate was mostly influenced by phosphate, nitrate, salinity and light penetration. Meanwhile, agar yield was mostly influenced by temperature and light penetration. Tissue culture produced seedling seem as promising to supply the need for seaweed farming which is a feasible alternative method.

\section{Acknowledgement}

This research was financially supported by state budget year of 2014. Sincere gratitude to Ir. Rohama Daud, MS for her guidance and direction, also all biotechnology laboratory technicians: Mujayana, Nur Amalia Ansari, Andi Angraeni, and Elmiwiya Batu Rante as a good team work.

\section{References}

Ak, I., Çetin, Z., Cirik, Ş. \& Göksan, T. 2011. Gracilaria verrucosa (Hudson) Papenfuss culture using an agricultural organic fertilizer. Fresenius Environ. Bull. 20(8a): 2156-2162. 
Angka, S.L. \& Suhartono, M.T. 2000. Bioteknologi Hasil Laut. Pusat Kajian Sumber Daya Pesisir dan Lautan Institut Pertanian Bogor. Bogor. $149 \mathrm{p}$.

Araño, K.G., Trono Jr, G.C., Montaño, N.E., Hurtado, A.Q. \& Villanueva, R.D. 2000. Growth, Agar Yield and Quality of Selected Agarophyte Species from the Philippines. Bot. Mar. 43(6): 517-524. doi: 10.1515/BOT.2000.051.

Baweja, P., Sahoo, D., García-Jiménez, P. \& Robaina, R.R. 2009. Seaweed tissue culture as applied to biotechnology: Problems, achievements and prospects. Phycological Res. 57: 45-58. doi: 10.1111/j.1440-1835.2008.00520.x.

Boyd, C.E. 1990. Water quality in pond for aquaculture. Alabama Agriculture Experiment Station. Auburn University. Birmingham Publ. Co, Alabama. USA. 482 p.

Choi, H.G., Kim, Y.S., Kim, J.H., Lee, S.J., Park, E.J., Ryu, J. \& Nam, K.W. 2006. Effects of temperature and salinity on the growth of Gracilaria verrucosa and $G$. chorda, with the potential for mariculture in Korea. J. App. Phycol. 18:269-277. doi: 10.1007/s10811006-9033-y.

Chung, I.C., Hwang, R.L., Lin, S.H., Wu, T.M., Wu, J.Y., Su, S.W., Chen, C.S. \& Lee, T.M. 2007. Nutrients, temperature, and salinity as primary factors influencing the temporal dynamics of macroalgal abundance and assemblage structure on a reef of Du-Lang Bay in Taitung in southeastern Taiwan. Bot. Studies 48: 419433.

Dawes, C.J., Kovach, C. \& Friedlander, M. 1993. Exposure of Gracilaria to various environmental conditions II. The effect on fatty acid composition. Bot. Mar. 36: 289-296. doi: 10.1515/botm.1993.36.4.289.

FAO. 2016. The State of World Fisheries and Aquaculture 2016. Contributing to food security and nutrition for all. Rome. 200 pp.

González-Gómez, M.A., Zertuche-González, J.A. \& Pacheco-Ruiz, I. 1992. Nitrogen effect on growth and carrageenan content in Gigartina canaliculata Harv. (Rhodophyta, Gigartinales) in outdoor tank cultures. Ciencias Marinas 18(4): 75-83. doi: 10.7773/cm.v18i4.911.

Effendi, H. 2003. Study of Water Quality: For Management of Water Resources and Environment. Kanisius. Yogyakarta, 257 pp.
Hayashi, L., Paula, E.J. \& Chow, F. 2007. Growth rate and carrageenan analyses in four strains of Kappaphycus alvarezii (Rhodophyta, Gigartinales) farmed in the subtropical waters of São Paulo State, Brazil. J Appl. Phycol. 19: 393-399. doi: 10.1007/s10811-006-9135-6.

Hurtado-Ponce, A.Q. \& Cheney, D.P. 2003. Propagule production of Eucheuma denticulatum (Burman) Collins et Harvey by tissue culture. Bot. Mar. 46: 338-341. doi: 10.1515/BOT. 2003.031.

Hurtado-Ponce, A.Q., Agbayani, R.F. \& Samonte-Tan, G.P.B. 1997. Growth rate, yield and economics of Gracilariopsis bailinae (Gracilariales, Rhodophyta) using fixed bottom long line method. Philippine J. Sci. 126(3): 251-260.

Husa, V. \& Sjøtun, K. 2006. Vegetative reproduction in "Heterosiphonia japonica" (Dasyaceae, Ceramiales, Rhodophyta), an introduced red alga on European coasts. Bot. Mar. 49: 191199. doi: 10.1515/BOT.2006.024.

Kim, Y.S., Choi, H.G., Kim, H.G., Nam, K.W. \& Sohn, C.H. 2002. Temperature and light responses in growth of Gracilaria verrucosa (Rhodophyta) and its potential for mariculture in Korea. Fisheries Aquatic Science 5(2): 108-113. doi: 10.5657/fas.2002.5.2.108.

Kumar, G.R., Reddy, C.R.K., Ganesan, M., Thiruppathi, S., Dipakkore, S., Eswaran, K., Rao, P.V.S., \& Jha, B. 2004. Tissue culture and regeneration of thallus from callus of Gelidiella acerosa (Gelidiales, Rhodophyta). Phycologia 43(5):596-602. doi: 10.2216/i0031-8884-435-596.1.

Kumar, V. \& Fotedar, R. 2009. Agar extraction process for Gracilaria cliftonii (Withell, Millar, \& Kraft, 1994). Carbohydrate Polymers 78: 813819. doi: 10.1016/j.carbpol.2009.07.001.

Li-hong, H., Madeline, W., Qian, P. \& Ming-yuan, Z. 2002. Effects of co-culture and salinity on the growth and agar yield of Gracilaria tenuistipitata var liui Zhang Et Xia. Chinese J. Oceanol. Limnol. 20(4): 365-370. doi: 10.1007/BF02847928.

Moore, J.W. 1991. Inorganic Contaminants of Surface Water Research and Monitoring Priorities. Springer-Verlag. New York. 334 p.

Marinho-Soriano, E. \& Bourret, E. 2003. Effects of season on the yield and quality of agar from Gracilaria species (Gracilariaceae, Rhodo- 
phyta). Bioresour Technol. 90(3): 329-333. doi: 10.1016/S0960-8524(03)00112-3.

Mubarak, H., Ilyas, S., Ismail, S., Hartati, S. T., Pratiwi, E., Jangkaru \& Arifuddin, R.. 1990. Manual for Seaweed Farming. Center of Fisheries Research and Development. Jakarta, 93 pp.

Mulyaningrum, S.R.H., Parenrengi, A., Risjani, Y. \& Nursyam, H. 2013. Formulation of Auksin (Indole Acetic Acid) and Citocinin (Kinetin, Zeatin) for Morphogenesis and its Effect on Growth, Survival and Regeneration rate of Seaweed, Kappaphycus alvarezii. J. Riset Akuakultur 8(1): 31-41. doi: 10.15578/jra.8.1. 2013.31-41.

Mulyaningrum, S.R.H., Daud, R, \& Badraeni. 2014. Vegetative Propagulation of Seaweed Gracilaria sp. Through Tissue Cuture Methods. J. Riset Akuakultur 9(2): 203-214. doi: 10.15578/jra. 9.2.2014.203-214.

Muñoz, J., Cahue-Lõpez, A.C., Patiño, R., \& Robledo, D. 2006. Use of plant growth regulators in micropropagation of Kappaphycus alvarezii (Doty) in airlift bioreactors. J. Appl. Phycol. 18: 209-218. doi: 10.1007/s10811-006-9105-z.

Orduña-Rojas, J. \& Robledo, D. 2002. Studies on the Tropical Agarophyte Gracilaria cornea J. Agardh (Rhodophyta, Gracilariales) from Yucatán, México Il.Biomass Assessment and Reproductive Phenology. Bot. Mar. 45: 459464.

Orduña-Rojas, J., Robledo, D \& Dawes, C.J. 2002. Studies on the Tropical Agarophyte Gracilaria cornea J. Agardh (Rhodophyta, Gracilariales) from Yucatán, Mexico. I. Seasonal Physiological and Biochemical Responses. Bot. Mar. 45: 453-458.

Orosco, C.A., Anong, C., Nukaya, M. Ohno, M. Sawamura, M. \& Kusunose, H. (1992). Yield and physical characteristics of agar from Gracilaria chorda Holmes: Comparison with those from Southeast Asian species. Nippon Suisan Gakkaishi 58 (9): 1711-1716.

Oyieke, H.A. 1993. The yield, physical and chemical properties of agar gel from Gracilaria species (Gracilariales, Rhodophyta) of the Kenya Coast. Hydrobiologia 260-261(1): 613-620. doi: 10.1007/BF00049079.
Paula, E.J., Erbert, C., \& Pereira, R.T.L. 2001. Growth rate of the carrageenophyte Kappaphycus arezii (Rhodophyta, Gigartinales) in vitro. Phycological Res. 49: 155-161. doi: 10.1046/j.1440-1835.2001.00235.x.

Pong-Masak, P.R., Priono, B. \& Insan, I. 2011. Selection of Clone seeding of seaweed, Gracilaria verrucosa. Media Akuakultur 6(1): 1-12. doi: 10.15578/ma.6.1.2011.1-12.

Raikar, S.V., lima, M. \& Fujita, Y. 2001. Effect of temperature, salinity and light intensity on the growth of Gracilaria spp. (Gracilariales, Rhodophyta) from Japan, Malaysia and India. Indian J. Mar. Sci. (30): 98-104.

Reddy, C.R.K., Kumar, G.R., Siddhanta, A.K., \& Tewari, A. 2003. In vitro somatic embryogenesis and regeneration of somatic embryos from pigmented callus of Kappaphycus alvarezii (Doty) Doty (Rhodophyta, Gigarti-nales). J. Phycol. 39: 610-616. doi: 10.1046/j.1529-8817.2003.02092.x.

Reddy, C.R.K., Jha, B., Fujita, Y. \& Ohno, M. 2008. Seaweed micropropagation techniques and their potentials: an overview. J. Appl. Phycol 20: 609-617. doi: 10.1007/s10811-007-9205-4.

Suryati, E., Tenriulo, A. \& Mulyaningrum, S.R.H. 2007. Isolation and protoplast culture of seaweed Kappaphycus alvarezii in laboratory. J. Riset Akuakultur 2(3): 399-405. doi: 10.15578/jra.2.3.2007.399-405.

Suryati, E. \& Mulyaningrum, S.R.H. 2009. Regeneration of Kappaphycus alvarezii (Doty) by in vitro induction of callus and embryo using plant growth regulator. J. Riset Akuakultur 4(1):3945. doi: 10.15578/jra.4.1.2009.39-45.

Thirumaran, G. \& Anantharaman, P. 2009. Daily Growth Rate of Field Farming Seaweed Kappaphycus alvarezii (Doty) Doty ex P. Silva in Vellar Estuary. World J. Fish Mar. Sci. 1 (3):144 $-153$.

Yudiati, E., Susilo, E.S. \& Suryono, C.A. 2004. Teknik Setting Spora Gracilaria gigas Sebagai Penyedia Benih Unggul dalam Budidaya Rumput Laut. IImu Kelautan. 9(1):37-40. doi: https://doi.org/10.14710/ik.ijms.9.1.37-4 